\title{
DEBT REDUCTION: INDICATIVE FACTORS IN CLASSIFICATION AS A DONATION FOR INCOME TAX PURPOSES
}

\author{
Rudie Nel* \\ Stellenbosch University
}

Received: January 2016

\author{
Andrea Herron" \\ Stellenbosch University
}

Accepted: May 2016

\begin{abstract}
Debt reduction in business is recognised for the economic relief afforded to the debtor involved. The new debt reduction regime was introduced in the Income Tax Act (section 19 and paragraph 12A of the Eighth Schedule) with the aim of minimising the tax impact so as not to negate the economic benefit. The new regime introduced an exclusion for debt reduced by way of a donation and uncertainty exists on instances where this exclusion would apply. This article considered four broad categories of factors indicative in the classification of a debt reduction as a donation (inadequate consideration; gratuitous waiver; intent and motive; classification as connected persons) and concluded with the formulation of such factors. The classification as connected persons is regarded as the most indicative of a debt reduction being classified as a donation, which could result in tax arbitrage if the creditor and debtor are taxed at different rates on the taxable income result of the debt reduction.
\end{abstract}

Keywords

Debt reduction, debt waiver, debt discharge, donation, section 19 , income tax

* Mr R Nel is a senior lecturer in the School of Accountancy, Stellenbosch University, South Africa. [rnel@sun.ac.za]

*Mrs A Herron is a lecturer in the School of Accountancy, Stellenbosch University, South Africa. 


\section{INTRODUCTION}

Amendments were made to provisions in the Income Tax Act 58 of 1962 ('the Act') in respect of a debt reduction during 2013 because Government sought a uniform system for the taxation treatment of debt reduction or relief to assist in local economic recovery. The role of debt reduction in general business and also in business rescue situations is therefore recognised (National Treasury, 2012; Seccombe, 2013). However, the possible tax imposed upon parties receiving the benefit of debt relief could potentially undermine the economic benefit of the relief if such relief is taxed (National Treasury, 2012). To this effect, the new debt reduction regime (section 19 and paragraph 12A of the Eighth Schedule) was introduced to replace the previous debt reduction regime (section $8(4)(\mathrm{m})$, section 20 and paragraph 12(5) of the Eighth Schedule) with the aim of minimising the tax impact of debt reductions so as not to negate the economic benefit.

It is posited that uncertainty regarding the application of income tax provisions could also undermine the application of the sections and the resulting potential economic benefit. The OECD (2009) recognises that tax risk is generally attributable to the uncertainty of the interpretation of tax law in relation to particular transactions. Furthermore, taxpayers should be aware of the tax consequences in order to structure their agreements in the most tax-beneficial way. Uncertainty regarding interpretation and application of tax provisions could result in incorrect interpretation, whether deliberately or not. The uncertainty of interest in this study is the classification of a debt reduction as a donation in terms of the new debt reduction regime. Under the previous debt reduction regime, there was no specific exclusion for donations; in fact, it is recognised that it could even have been a donation as well as a recoupment (0livier, 2006:305; Dachs, 2015:29). Under the new debt reduction regime the extent to which the debt is reduced by way of a donation as defined in section 55(1) or a deemed donation in terms of section 58 it would now be specifically excluded from normal tax and potentially subjected to donations tax. This exclusion rests on the proposition to avoid double taxation as such a reduction would then fall within the ambit of donations tax. The South African Revenue Service (SARS, 2015) has provided further guidance on section 19 and paragraph 12A of the Eighth Schedule in the form of an Interpretation Note, which is currently only available in draft format, but no guidance is provided as to when a debt reduction would be regarded as a donation.

National Treasury (2012) also recognises that at issue is debt owed by a debtor that is reduced or cancelled for less than full consideration and could also be treated as a donation, but no further guidance has been provided to this effect. Wilcocks (2014:315) submits that the debt reduction would fall within the ambit of the new debt reduction regime if it results from a debtor's inability to pay (implying that it is thus not considered to be a donation). National Treasury (2012) has, however, indicated that such a reduction or cancellation could still fall within the ambit of the new debt reduction regime even if it is not as a result of the debtor's inability to pay. According to KPMG (2013), the real benefit of the exemption of a donation from the debt reduction rules seems to be directed at debt waivers in corporate group scenarios, in which case the vexed question would be whether it can truly be said to be driven by a gratuitous disinterested benevolence. Rudnicki and Bird (2014) concluded that it is unlikely that the donations tax exemption would apply in the vast majority of debt waivers. Taxpayers could therefore be confronted with the uncertainty as to whether such a debt reduction is a donation and the resulting application of the new debt reduction regime. 
If the debt reduction is regarded as a donation there would be no immediate normal tax consequences for the debtor. The argument in favour of the receipt or accrual being of a capital nature, as it was not obtained in a scheme of profit-making, would then be merited. Furthermore, as the debtor did not dispose of an asset on the date of the debt reduction, there would also be no capital gains tax consequences as the deeming disposal provisions of paragraph $12 \mathrm{~A}$ would not apply. The only conceivable consequences for the debtor would be on subsequent disposal of the underlying asset (funded by the debt reduced) when paragraph 20(3)(b) is applied to reduce the base cost of the asset as the initial expenditure incurred is reduced as a result of the debt reduction. There would therefore not be an immediate recoupment of expenditure as the case may be under the new debt reduction regime if debt funded the acquisition of trading stock already sold, or deductible trade expenditure. Based on this argument it might even be more beneficial for the debtor to regard the debt reduction as a donation which may promote the intent to provide the best possible economic relief in respect of the debt reduction.

Uncertainty regarding the tax treatment of a debt reduction as a donation (or not) therefore exists, as does the resulting application of the provisions of the new debt reduction regime. The quality of certainty entails that the tax which a person is bound to pay should be certain and not arbitrary (Venter et al., 2008:3). This means that the timing and manner of payment, as well as the amount, ought to be clear and certain. The uncertainty regarding the classification of a debt reduction as a donation would result in uncertainty regarding the timing and amount of the resulting tax consequences. Such uncertainty should be clarified in an attempt to provide guidance to taxpayers entering into an agreement for the reduction or cancellation of debt. Rudnicki and Bird (2014) focussed on donation as an exemption in their study but only in corporate debt waiving scenarios (between companies). Therefore, the study on which this article is based sought to add to the literature by including individuals (natural persons) in the discussion. Furthermore, in an attempt to provide guidance and certainty in the donations' exclusion this study also investigated the effect of classification as connected persons for which no existing literature could be identified.

\section{RESEARCH OBJECTIVE AND RESEARCH METHODOLOGY}

A literature review was employed as research method. According to the Harvard Graduate School of Education (n.d.), a literature review could serve as a stand-alone form of qualitative research for researchers who attempt to summarise extant theory in order to identify lacking theory or research in order to take an analytical stance towards it and do not merely summarise reported research. In this study the available literature on donations and debt reductions was considered in order to identify and take an analytical stance on the indicative factors in the classification of a debt reduction as a donation. At present, there is a gap in the research literature on this matter. The objective of the study was to investigate such factors to provide guidance by formulating such indicative factors in the classification of a debt reduction as a donation. Such an investigation was not intended to be exhaustive by any means but rather intended to provide factors to be considered by taxpayers in tax planning and to serve as a basis for further academic endeavours to provide further guidance regarding the topic.

Literature from authoritative dictionaries, popular and academic publications, case law and publications from the South African Revenue Service (SARS) was consulted for interpretation of the terms 'donations' and 'debt reduction' (or 'debt discharge'). Limited reference was also made to Australian literature to supplement arguments in this study. Similarities between South African 
and Australian legislation have been noted in case law (CIRv Mangalese Metal Co (Pty) Ltd (1996)

(3) SA 591) and comparisons performed in other studies (Willemse, 2011).

The following steps were followed in conducting the study:

- Firstly, the definition of a donation was considered. The provisions of section 55 and section 58 were used as point of departure. This step culminated in the broad categories of factors to be investigated further;

- Secondly, specific factors for each broad category were investigated based on the literature in the context of debt reduction; and

- Lastly, the specific indicative factors in the classification of a debt reduction as a donation were formulated in a conclusion.

\section{DEFINITION OF A DONATION}

In the case of CIR $v$ Estate Merensky (1959) 2 All SA 501 (A) it was held that a donation may be looked at from the angle of the recipient of the benefit as well as from the angle of the donor who divests himself of something. Therefore, the donee has to gain an advantage from the transaction and the donor has to give up something in order for the transaction to be classified as a donation. On the one hand, where a debt is reduced or discharged, the debtor gains an advantage by not having to repay the debt to the creditor, thereby benefitting from the transaction. On the other hand, the creditor discharges his right to claim any form of payment from the debtor in the future, whereby he forsakes the possibility of any economic benefits. From this common law perspective it would appear as if a debt reduction is in fact a donation, however, the statutory definition in section 55 of the Act also requires consideration.

The statutory definition in terms of section $55(1)$ is used as point of departure and defines a donation as follows: 'any gratuitous disposal of property including any gratuitous waiver or renunciation of a right'.

In addition to the statutory definition above, section 58 also contains the following deemed donations provision: 'Property disposed of under certain transactions deemed to have been disposed of under a donation. - (1) Where any property has been disposed of for a consideration which, in the opinion of the Commissioner, is not an adequate consideration that property shall for the purposes of this Part be deemed to have been disposed of under a donation: Provided that in the determination of the value of such property a reduction shall be made of an amount equal to the value of the said consideration.'

In the past, the courts have often been given the important task of deciding whether a transaction constitutes a donation or not. Case law has been used to establish certain characteristics of the term 'donation' based on interpretation in both Supreme Court and Tax Court cases. Therefore, if a debt reduction is classified as a donation (section 55(1)) or a deemed donation (section 58), it would be specifically excluded from the new debt reduction regime. Both these provisions refer to the disposal of property as a starting point.

Section 55(1) defines 'property'as any right in or to property movable or immovable, corporeal or incorporeal, wheresoever situated. A debt reduction pertains to a right which is waived by the creditor and would therefore constitute 'property'. Such a waiver would in turn also qualify as a 'disposal'. According to De Koker (2011), under the law of contract, the relinquishment or abandonment of a debt by a creditor is generally described as a 'waiver' of his right. The mere 
suspension of a debt would, however, not constitute a waiver (Du Toit, 2012:26). If the waiver of such right is gratuitous the debt reduction could therefore be classified as a donation in terms of section 55(1). Factors indicative of a debt reduction being regarded as gratuitous is a broad category investigated based on existing literature. Section 58 does not specifically include the gratuitous waiver or renunciation of a right but would still qualify as 'property disposed'. A debt reduction would in principle then be deemed a donation in terms of section 58 if the Commissioner considers the consideration to be inadequate and is thus a broad category investigated based on existing literature.

The intent and motive of the parties to the debt reduction agreement would also be considered as a possible a broad category of factors which could be indicative in the classification of a debt reduction as a donation. The intent and motive could affect the decision whether such a reduction was intended to be gratuitous and whether the intent was in fact to reduce it as inadequate consideration. In the context of gratuitous waiver and intent it was also investigated whether the classification as connected persons could be indicative in the classification of a debt reduction as a donation. According to KPMG (2013), in the context of business, the implication is that debts between independent parties are unlikely to be disposed of under a donation. Classification as connected persons would have an impact on the principle of adequate consideration and the intent of the parties to the debt reduction transaction.

The following broad categories of factors are therefore subsequently discussed in order to identify and formulate specific indicative factors in the classification of a debt reduction as a donation for income tax purposes:

- Inadequate consideration according to the Commissioner

- Gratuitous waiver

- Intent and motive

- Classification as connected persons

\section{INADEPUATE CONSIDERATION ACCORDING TO THE COMMISSIONER}

A donation can be present where a transaction is settled at an amount deemed inadequate by the Commissioner in terms of section 58 of the Act. In terms of this section, a deemed disposal occurs when the consideration received is inadequate according to the Commissioner and does not have the gratuitous waiver requirement contained in section 55. Boshoff JA clarified in the case Ogus $v$ Secretary for Inland Revenue (1972) (3) SA 67(T) that consideration in the context of section 58 is used in the sense of a quid pro quo, compensation or reward having some value. Therefore, if the counter-performance has any value, it can be regarded as consideration. If the transaction was made and no quid pro quo was expected in return, it will be regarded as a donation. If the counter-performance has a value that is below adequate consideration, the Commissioner may determine that the transaction is a deemed a donation in terms of section 58 . The same principle is revisited in ITC 1599 (1995) 58 SATC 88, where the Commissioner did not consider acceptable consideration to imply that a transaction occurred at fair market value. A transaction where acceptable consideration is less than fair value it constitutes a deemed donation. In ITC 1745 (2002) 65 SATC 181, it was held that irrespective of what the intent of the taxpayer was, if the Commissioner deems the consideration to be inadequate, the transaction qualifies as a deemed donation. Rudnicki and Bird (2014) concluded in a corporate debt-waiver scenario that in a case, for example, where the debtor is factually incapable of repaying there might be an argument that 
'adequate consideration' has, in fact, not been provided, resulting in the non-application of the deemed donation provisions.

The SARS therefore retains the statutory right in terms of section 58 to deem an amount as a donation for donations tax purposes. It is posited that this would, however, serve as an antiavoidance measure and not be the default consideration of a bona fide debt reduction scheme. On the application of section 58(1) and what constitutes adequate consideration according to the SARS, Binding Rulings have been issued in the past (refer Binding Private Ruling No 095 of 2011 (SARS, 201la)). No specific guidance or rulings were noted during the investigation as to the SARS's intent to apply section 58 in the context of bona fide debt reduction transactions.

The next sections examine the common law interpretation in respect of donations and literature on factors indicative of a bona fide debt reduction scheme being classified as a donation. The first point of investigation would be to examine factors in the interpretation of gratuitous waiver in the context of debt reduction.

\section{GRATUITOUS WAIVER}

For a debt reduction to qualify as a waiver the creditor should abandon a right to claim outstanding balances from the debtor. The creditor should thus not retain any future right to possibly recover the said amounts from the debtor. Van Vuuren (2014) emphasises that the financial impairment of an asset, as an accepted accounting practice, cannot be said to be tantamount to a permanent abandonment of debt. Consequently, debt reduction would not be regarded as a donation where it is evident that it is only recognised by the creditor as an accounting impairment. Furthermore, in Welch's Estate v CSARS (2005) (4) SA 173 (SCA) it was held that for such a waiver, or disposition, to be regarded as a donation it must be motivated by pure liberality or disinterested benevolence and not by self-interest or the expectation of a quid pro quo of some kind from whatever source it may come.

Under the new debt reduction regime in section 19 of the Act a 'reduction amount' is defined as the amount by which debt is reduced which exceeds the consideration for that reduction and thus only deals with the portion at no consideration. Therefore, if such debt reduction is affected without the debtor having to provide any other consideration (or quid pro quo), such debt reduction could be argued to be a donation made out of 'pure liberality or disinterested benevolence'. De Koker (2011), however, submits that a gratuitous payment would not constitute a donation if in pursuance of a legal duty and not from 'pure liberality or disinterested benevolence'. An example of one such legal duty could be where a business rescue plan is initiated in terms of Chapter 6 of the Companies Act 71 of 2008 which may provide for the discharge of debts and claims relating to a company. According to Du Toit (2012:26), the waiver or reduction of debt during business rescue proceedings would probably have resulted in the application of the previous debt reduction regime. Under the new debt reduction regime, if debt is reduced based on business rescue proceedings, a legal duty, it would not constitute a donation and therefore would result in the application of the new debt reduction regime.

In addition, Olivier (2006:310) argues that a company capitalising a loan account of shareholders/creditors considered technically insolvent would not be subject to donations tax. The reason is that at the time of capitalisation the one worthless asset (the loan account) is merely replaced by another worthless asset (the shares) and therefore that no asset is disposed of for less than its market value. In the context of debt reduction under the new debt reduction 
regime, it is therefore posited that if the debt reduction occurred as a result of the insolvency it would not constitute a donation. This view is supported by Wilcocks (2014:315) who submits that the debt reduction would fall within the ambit of the new debt reduction regime if it results from a debtor's inability to pay. Therefore, a debt reduction due to insolvency would not be regarded as a donation and would fall under the new debt reduction regime even though it would demonstrate a characteristic of a donation which is at inadequate consideration.

Based on gratuitous waiver, factors that would be indicative of a debt reduction being regarded as a donation if it is not a mere accounting impairment by the creditor (it should therefore be an actual waiver), if not in pursuance of a legal duty, and if not due to inability of the debtor to pay. It was also submitted in the Australian case of Tasman Group Services Pty Ltd v Commissioner of Taxation of the Commonwealth of Australia (2008) FCA 23 that a waiver is not limited to requiring some express forgiveness but could also be as result of conduct. It is therefore an intentional act carried out with knowledge whereby a person abandons a right by acting in a manner inconsistent with that right ( $/$ bid.). A write-off of debt is regarded as an intentional decision by the creditor. Therefore it can be argued that depending on the intent of the creditor, the amount can either be a donation or not.

The next section examines the role of intent and motive in the possible classification of a debt reduction as a donation.

\section{INTENT AND MOTIVE}

The intent of the taxpayer in concluding a transaction or agreement is often referred to as the golden rule in interpretation. It therefore needs to be established if the taxpayer's intent would be decisive in the classification of a debt reduction as a donation. In ITC891 (1959) 23 SATC 354(C) it was held that the intent to enrich the donee is an important factor in establishing whether a transaction qualifies as a donation or not. It is stated that if the intent of the donor is to enhance the donee, it could possibly indicate a donation or a gift. Meyerowitz (2005:§31.5) also recognises the importance of intent (animo dinandi) in considering a donation in terms of section 55(1) but stresses the deemed donation's provisions in terms of section 58 .

The fact that a debt is discharged by operation of law (the debt is prescribed) does not necessarily mean that the creditor has not taken an action to discharge a debt. If a debt is prescribed it would not disqualify it from application of the new debt reduction regime. It was held in previous South African tax court cases that the act of adiation was a donation even though what followed was by operation of law under section 37 of the Administration of Estates Act (SARS, 2011b:92). Therefore, when a creditor allows a debt to become prescribed through the effluxion of time, this act of omission does amount to the reduction or discharge of the debt and still necessitates consideration of the intent of the creditor to determine if it qualifies as a possible donation.

If the creditor can prove a business motive in effecting the debt reduction, such business motive would result in the debt reduction not being regarded as donation. In a business context the debt reduction can then be argued as not as gratuitous or out of disinterested benevolence. SAICA (2015:9) indicates that for the purpose of applying section 19 the context will indicate whether it is a commercial decision (business motive) or a donation. From this it might be inferred that a donation can be distinguished from a transaction incurred as commercial decision. Often the need for such a reduction of group debt may be driven by other business reasons, such as establishing liquidity or solvency in the debtor entity or improving the debtor entity's balance sheet (KPMG, 
2013). Meyerowitz (2005:§31.5) also recognises that the argument in a group context may be based on the proposition that the donor was not impoverished because of the enhancement in the value of the shareholding. In addition, Olivier (2006) also submits that a creditor would not be motivated by pure liberality or generosity to release a debtor from an outstanding liability if the creditor decides not to enforce payment as, for example, where it would be too costly to enforce the debt as the whereabouts of the debtor is unknown. Therefore, the decision not to enforce based on cost consideration is not a donation as it is rather motived by a business decision based on costs to recover.

Based on intent and motive, a factor indicative of a debt reduction being regarded as a donation would be if there is no business motive of intent. However, Lambooij (2006) notes that in relatedparty situations debt waivers are a more sensitive form of debt restructuring as it is often difficult to distinguish between bona fide business reasons and shareholder motives.

The next section examines the role of connected persons in the possible classification of a debt reduction as a donation in the context of gratuitous waiver, motive and intent.

\section{CLASSIFICATION AS CONNECTED PERSONS}

According to Kruger (2010), related-party or connected persons transactions are essentially antiavoidance in nature and seek to ensure that related parties do not use their relationship to avoid or postpone the payment of the relevant tax. Furthermore, Lambooij (2006) states that complications usually arise in the case of debt restructurings between related parties, specifically in the area of waivers, as governments view these with suspicion because of their arm's length character. The South African Income Tax Act currently contains various provisions, inter alia, section $8(4)(k)$ and paragraph 38 of the Eighth Schedule, aimed at accounting for transactions at market value for tax purposes between connected persons. In the context of classification of a debt reduction as a donation, the possible impact of classification as connected persons is investigated. In this study connected persons were defined as other than companies forming part of the same group of companies, as paragraph 12A specifically excludes persons in group of companies context.

According to KPMG (2013), in the context of business, the implication of the exclusion of a donation from the new debt reduction regime is that debts between independent parties are unlikely to be disposed of under a donation. The real benefit of the exemption of a donation from the debt reduction rules seems to be directed at debt waivers in corporate group scenarios (KPMG, 2013) - therefore interpreted as directed to connected party creditors. This indicates that for judicial persons the fact that they are connected might support the classification of a debt reduction as a donation.

It was, however, necessary to determine whether the same holds true for natural persons (individuals) who are connected persons as well. The interpretation of a specific provision in the Australian Income Tax Assessment Act regarding natural persons was considered valuable for this investigation. Section 245-40 of the Australian Income Tax Assessment Act lists the exclusions from the Australian debt reduction regime which agrees in most parts to the exclusions contained in section 19(8) of the South African Income Tax Act. A difference that was noted and considered relevant is that the Australian Income Tax Assessment Act contains no exclusion for any donations (as no donations tax provisions are currently in force in Australia) but contains a specific exclusion if the write-off is effected by 'natural love and affection'. It is posited that this 
exception will only be applicable to natural persons, as judicial persons are without human feelings. It can thus be argued that a person who has natural love or affection towards another person will waive a loan gratuitously, without an expectation of quid pro quo, and that it therefore constitutes a donation. Where natural persons meet the definition of connected persons in section $l$ of the Act it is therefore posited that the action is driven by love and affection, and therefore merits the argument in favour of a donation rather than a debt reduction subjected to the new debt reduction regime. Therefore, in addition to the observation by KMPG (2013) regarding the exclusions as donation from the new debt reduction regime benefitting judicial persons, it is submitted that there is a strong argument in favour of a debt reduction being classified as a donation between natural persons.

The aforementioned discussions considered the tax position of the debtor. However, the classification of the parties as connected persons and the debt reduction as a donation would also affect the creditor in such a transaction. Paragraph 56 of the Eighth Schedule determines that a creditor must disregard any capital loss which arises from a reduction of debt unless the connected debtor applied paragraph 12A. Therefore, if the debt reduction is seen as a donation and it is therefore exempt from the provisions of paragraph 12A, the creditor has to disregard the capital loss in respect of the reduction of the loan if the debtor is a connected person. The approach of disallowing the deductibility is similar to the approach followed by other Governments as well (Lambooij, 2006:60). As the tax position of the creditor is also affected by the classification, the possibility of tax arbitrage could arise if the creditor and debtor are subject to different tax rates on the taxable income in respect of the debt reduction. Bekker and Aitchison (2013) note that there is often a common purpose between connected persons with the opportunity to move income around to achieve a better tax result and that some tax arbitrages exist only as a result of specific rules created by Government. The specific rule of excluding donations from the new debt reduction regime could afford connected persons the opportunity for tax arbitrage if the creditor and the debtor are taxed at different rates on the taxable income as a result of the debt reduction.

The classification as connected person is therefore submitted as an indicative factor of a debt reduction being regarded as a donation. Furthermore, the classification as connected persons is also submitted as the most indicative factor of all the broad categories of factors considered, since the classification of connected persons is well established in the South African Income Tax Act whereas the other broad categories of factors are principle-based and dependent on the fact and circumstances of every transaction.

\section{CONCLUSION}

Classifying a debt reduction as a donation could be beneficial to the debtor depending on the specific circumstances. It is conceivable that in circumstances where a debt reduction takes place in respect of a debt owed by a South African resident to a non-resident, donations tax will also not be payable since the donation is made by a non-resident and therefore not subjected to the provisions of the new debt reduction regime (PwC, 2013:28). Not classifying the debt reduction as a donation would result in the application of the new debt reduction regime, which in effect reduces the deductible expenditure for the debtor in respect of an asset funded by such debt and still on hand (which reduces any remaining reduction amount). Any remaining amount of the debt reduction would then be included in gross income as a recoupment and would result in immediate tax consequences for such a debtor. 
Based on a purposive interpretation of the new debt reduction regime, economic relief should be provided to the debtor involved in such a transaction. However, the uncertainty which currently exists in the classification of debt reduction as a donation could undermine such relief. Based on the study, various factors were noted which could be indicative of a debt reduction as a donation. Such factors are formulated in TABLE 1 .

\section{TABLE 1: Indicative factors in classification as a donation}

INADEQUATE CONSIDERATION ACCORDING TO THE COMMISSIONER

- No current indication of debt reductions being specifically regarded as within the scope of section 58

\section{GRATUITOUS DISPOSAL}

- Not a mere accounting impairment by creditor

- Not in pursuance of a legal duty

- Not due to inability of debtor to pay / insolvency

\section{INTENT AND MOTIVE}

- Irrelevant if Commissioner deems consideration inadequate

- Not as a result of a business or commercial decision

- Not as a result of creditor's decision not to enforce payment due to cost considerations

\section{CLASSIFICATION AS CONNECTED PERSONS}

- If between connected parties argument merited in favour of a donation

Source: Author's deduction

The findings of this study indicate that there are indicative factors in the classification of a debt reduction as a donation and such classification would result in exclusion from the application of the new debt reduction regime. The classification of the parties to the transaction as connected persons is submitted as the most indicative of a debt reduction being classified as a donation and could also afford connected persons the opportunity for tax arbitrage if the creditor and debtor are taxed at different rates on the taxable income as a result of the debt reduction.

However, although the other broad categories are submitted as indicative there could still be some uncertainty regarding other factors not considered in this study, as held in the case of Estate Reynolds and Others V CIR (1937) AD 57 that in the case of an ambiguity (or uncertainty) a fiscal provision should be construed contra fiscum (construed in favour of the subject of the tax). In the context of the uncertainty of the classification of a debt reduction as a donation it might well mean that the debt reduction should be construed as a donation, with no immediate tax consequences for the debtor, as opposed to the application of the new debt reduction regime.

The findings of this study could be the basis for further research or discussion on the current uncertainty which has been illustrated by these indicative factors. The policy implications of this study are therefore that the necessary guidance should be given to assist taxpayers in their assessment and classification of a debt reduction as a donation. 


\section{LIST OF REFERENCES}

Bekker, A. \& Aitchison, J. (2013). Significant changes to interest deductibility proposed. Tax Breaks Newsletter, August 2013 Issue 331:4-6.

CIR v Estate Merensky (1959) 2 All SA 501 (A).

CIR v Mangalese Metal Co (Pty) Ltd (1996) (3) SA 591.

Dachs, P. (2015). Tax consequences arising from the writing off of loans: income tax. Tax Professional 23: $27-29$.

De Koker, A.P. et al. (2011). Silke on South African Income Tax. § 24.33 Deemed disposals - reduction or discharge of a debt. Durban: LexisNexis.

Du Toit, L. (2012). Tax implications for business rescues in South African Law, LLM dissertation, University of Pretoria, Pretoria. Available: http://upetd.up.ac.za/thesis/available/etd-07242013124358 (Accessed 14 November 2014).

Estate Reynolds and Others v CIR (1937) AD 57.

Harvard Graduate School of Education (n.d.). Foundations of qualitative research in education. Available: http://isites.harvard.edu/icb/icb.do?keyword=qualitative\&pageid=icb.page350640 (Accessed 22 September 2015).

ITC 891 (1959) 23 SATC 354(C).

ITC 1599 (1995) 58 SATC 88.

ITC 1745 (2002) 65 SATC 181.

KPMG. (2013). Debt Waivers: Reduction/Cancellation of debt. Available:

http://www.kpmg.com/za/en/issuesandinsights/studyspublications/tax-and-legalpublications/pages/debt-waivers.aspx (Accessed 24 October 2014).

Kruger, D. (2010). Related-party transactions - there be dragons!. Business Tax and Company Law Quarterly 1(1): 14-23.

Lambooij, M.V. (2006). The tax consequences of restructuring of indebtedness (debt work-outs). General Report: International Fiscal Association. [0n-line] Available:

http://www.freshfields.com/en/knowledge/The_tax_consequences_of_restructuring_of_indebtedne ss_(debt_work-outs). (Accessed 21 September 2015).

Meyerowitz, D. (2005). Meyerowitz on income tax. 2005-2006 edition. The Taxpayer: Cape Town.

National Treasury (South Africa). (2012). Explanatory Memorandum of the Taxation Laws Amendment Bill 2012. Government Printers: Pretoria.

OECD. (2009). Forum on Tax Administration. Information Note General Administrative Principles:

Corporate governance and tax risk management. [0n-line] Available:

http://www.oecd.org/dataoecd/37/19/43239887.pdf (Accessed 5 November 2014).

Ogus v Secretary for Inland Revenue (1972) (3) SA 67(T).

Olivier, L. (2006). Reduction or discharge of debts: The hidden tax dangers. Stellenbosch Law Review = Stellenbosch Regstydskrif, 17(2): 302-313.

PwC. (2013). Briefing on the 2012 Taxation Laws Amendments Acts. PwC Tax Law Review, April 2013. 
Rudnicki, M. \& Bird, N. (2014). The Debt-Waiver Rules and their Exemptions. Business Tax \& Company Law Quarterly, 5(4): 52-63.

SAICA. (2015). Initial Test of Competence 2016: Taxation Examinable Pronouncements. [0n-line] Available: https://www.saica.co.za. (Accessed 7 April 2015).

SARS. (2011a). Binding Private Ruling Number 095. [0n-line] Available: http://www.sars.gov.za. (Accessed 30 September 2015).

SARS. (2011b). Comprehensive Guide to Capital Gains Tax (Issue 43). [0n-line] Available: http://www.sars.gov.za. (Accessed 240 october 2014).

SARS. (2015) Draft Interpretation note on reduction of debt. [0n-line] Available: http://www.sars.gov.za (Assessed 8 0ctober 2015)

Seccombe, D. (2013). Proposed tax amendments will assist business rescue. TAXtalk, 38:40-41.

South Africa. (1962). Income Tax Act No. 58 of 1962 (as amended). Pretoria: Government Printer.

Tasman Group Services Pty Ltd $v$ Commissioner of Taxation of the Commonwealth of Australia (2008) FCA 23.

Van Vuuren, M. (2014). Impairment is not abandonment. Werksmans Attorneys Legal Brief. [On-line] Available: http://www.werksmans.com/legal-briefs-view/impairment-abandonment/ (Accessed 18 May 2015).

Venter, J.M.P. et al. (2008). A Student's Approach to Income Tax. Durban: LexisNexis.

Welch's Estate v C: SARS 2005 (4) SA 173 (SCA), 66 SATC 303.

Wilcocks, J. (2014). Special deductions and assessed losses. In: Stiglingh M., Koekemoer A., Van Schalkwyk L., Wilcocks J.S., De Swardt R., Jordaan K. (eds.) SILKE: South African income tax. Durban: LexisNexis.

Willemse, L.C. (2011). Die inkomstebelastinghantering van aanvangsfranchisefooie betaalbaar in die Suid-Afrikaanse petroleumbedryf. Journal of Economic and Financial Sciences, 2011(4): 407-426. 